\title{
Depositional environment interpretation and development of the Renanué section (Upper Eifelian-Lower Frasnian; Pyrenees, N. Spain)
}

\author{
JAU-Chyn LIAO, PETER KÖNIGSHOF, JOSÉ I. VALENZUELA-RíOS \& EBERHARD SCHINDLER
}

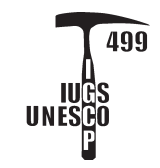

\begin{abstract}
Microfacies analysis combined with palaeontological studies on Middle to Upper Devonian marine carbonates exposed at the section Renanué in the Pyrenees, northern Spain, allow recognition of an open-shelf environment. Several eustatic changes through the Givetian and lower Frasnian are recorded, discriminated by detailed conodont control. A transgressive pulse represented by a deepening trend from an open-shelf setting to deep-shelf environment around the Lower-Middle Givetian transition is more likely related to a regional event. A second important transgression is present in the upper half of the Middle varcus Zone (Middle Givetian); its correlation with the Taghanic Event is still a matter of discussion. A third important transgressive pulse is recognized close to the Middle-Upper varcus Zone boundary [see above], still in the Middle Givetian. A paraconformity spanning from, possibly, already the Upper varcus Zone through, at least, the upper disparilis Zone precludes further analysis of paleoenvironmental development at the Renanué section. The reason for this lack of sediments is unknown, but bottom currents have been considered as the explanation for such gaps in similar deposits of, approximately, the same age in several European and Moroccan sequences. Finally, a transgressive trend is inferred from the uppermost Givetian into the lowermost Frasnian also recognizable by a change in conodont biofacies that took place at the basal part of the Frasnian and is represented by the absence of Icriodus and the arrival of Klapperina and Mesotaxis. $\bullet$ Key words: Middle-Upper Devonian, conodonts, microfacies analysis, sea-level curve, Spanish Pyrenees.
\end{abstract}

LiAO, J.-C., KÖNIGShOF, P., VAlEnZUElA-Ríos, J.I. \& SCHINDlER, E. 2008. Depositional environment interpretation and development of the Renanué section (Upper Eifelian-Lower Frasnian; Pyrenees, N. Spain. Bulletin of Geosciences 83(4), 481-490 (4 figures). Czech Geological Survey, Prague. ISSN 1214-1119. Manuscript received July 4, 2007; accepted in revised form December 15, 2008; issued December 31, 2008.

Jau-Chyn Liao, Dpto. de Paleontología, Facultad de Ciencias Geológicas, Universidad Complutense, E-28040 Madrid, Spain \& Dpto. de Geología, Universitat de València, Dr. Moliner 50, E-46100 Burjassot, Spain; Jau.Liao@uv.es - José Ignacio Valenzuela-Ríos, Dpto. de Geología, Universitat de València, Dr. Moliner 50; E-46100 Burjassot, Spain; Jose.I.Valenzuela@uv.es・Peter Königshof \& Eberhard Schindler, Forschungsinstitut Senckenberg und Naturmuseum, Senckenberganlage 25, D-60325 Frankfurt am Main, Germany; peter.koenigshof@senckenberg.de, eberhard.schindler@senckenberg.de

The complexity of facies development and tectonics makes it difficult to understand the relationships among different Devonian stratigraphical sequences in the Pyrenees. The first attempt in arraying stratigraphical data in a more or less coherent set of units was presented by Mey (1967). This author recognized four mayor "facies areas" for the Devonian and Lower Carboniferous of the Central Pyrenees (Central, Southern, Northern and North-Pyrenean); they were further subdivided into major "sub-facies areas"; for instance, the Southern facies area was subdivided into the Sierra Negra, Baliera and Renanué subfacies areas; later Hartevelt (1970) added the Compte "subfacies area". Major faults, "Cambro-Ordovician Domes" or large intrusive bodies separate these units. This initial subdivision has more or less maintained in subsequent works, but different authors group the units of the Southern facies area in different ways (irrespective of the terminological change from "sub-facies area" to "Domains" proposed by Sanz-López, 2002). For the purpose of this paper the discussion will focus on the Sierra Negra, Baliera and Renanué "subfacies areas", mainly in the latter.

Boersma (1973) was the first to change the subdivision proposed by Mey (1967) and to group the Sierra Negra and Baliera sub-facies into de Sierra Negra sub-facies s.l. He maintained the validity of the Renanué sub-facies. Subsequently, Zwart (1979, fig. 6) maintained the original subdivision of Mey between Sierra Negra and Baliera sub-facies, but called them "areas" within a larger Sierra Negra sub-facies. In this work, the original Renanué sub-facies is included into the Baliera area. The latter opinion was also 


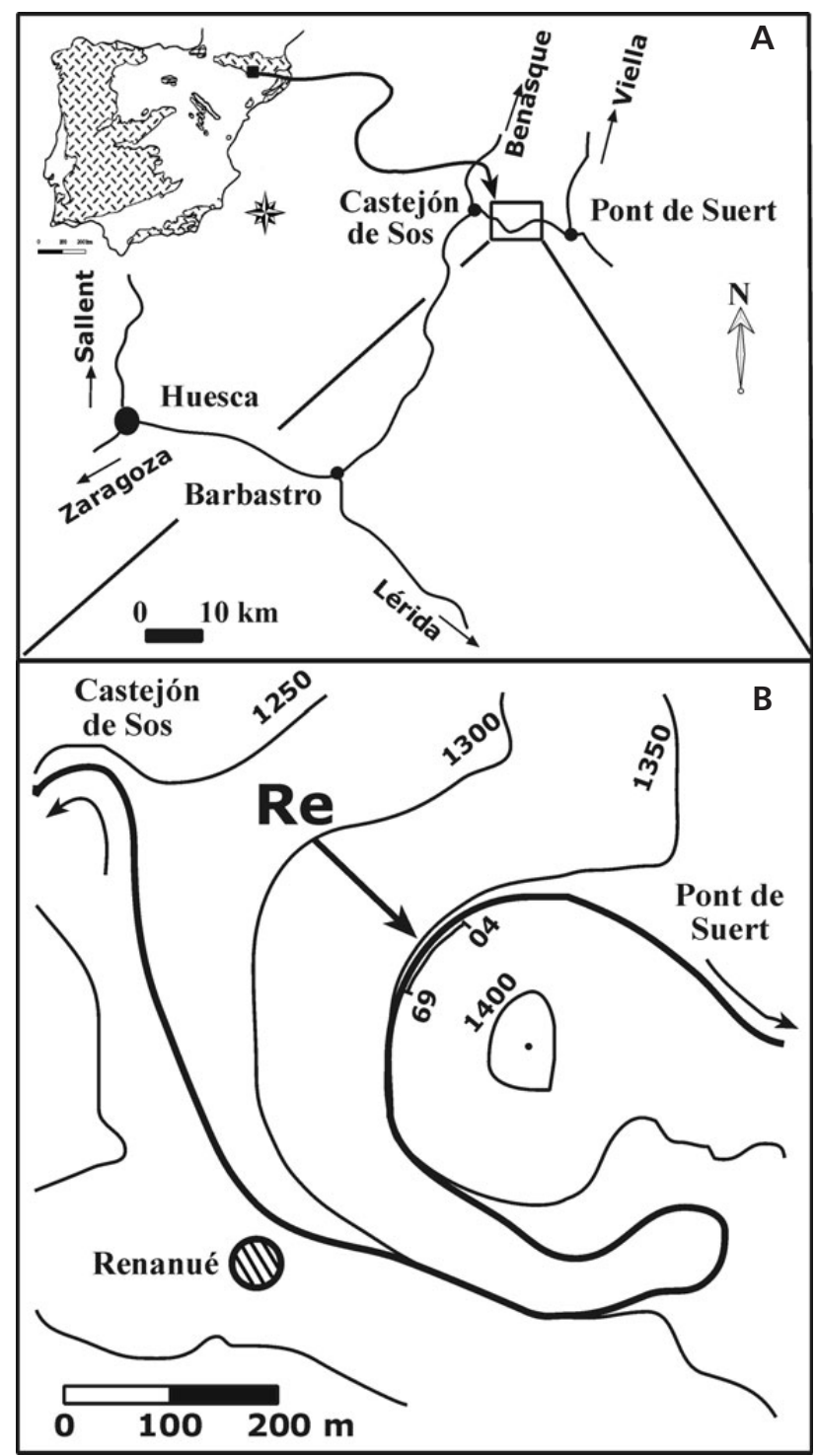

Figure 1. Location of Renanué section, Aragonian Pyrenees, N Spain: 04 and 69 are position of respective beds. espoused by Valenzuela-Ríos \& Sanz-López (2002) and Sanz-López (2002) where the Renanué Limestone (informal stratigraphical unit that includes the limestone rocks outcropping in the Renanué area) is placed above the Vilaller Formation in the Baliera area (or subdomain). However, the stratigraphical relationships between the Renanué Limestone in the Renanué area and the supposed underlying and overlying rocks of the Baliera unit are unknown. Moreover, the Renanué Limestone is not exposed in the tectonic unit represented by the Baliera area (Benasque Alpine Unit, Valenzuela-Ríos \& Sanz-López 2002, fig. 6.14) but it does in the one represented by the Nogueras Unit, or better, the Nogueras Zone of Dalloni (1910). Most of the Devonian outcrops of the Nogueras Zone belong to a type of facies that was named by Hartevelt (1970) as the "Compte Subfacies"; however, the Middle and Upper Devonian rocks of the Renanué area do not belong to this subfacies; initially, because of the lithological features a different sub-facies term was coined "the Renanué sub-facies" (Mey 1967).

Above, we have already commented on the different attributions of this subfacies according to subsequent authors. In this paper we maintain the independence of these rocks from other sub-facies or (sub) domains; as they belong to a minor tectonic unit within the Nogueras Zone (the Laspaúles Block) and the stratigraphical relation to any of the previous sub-facies is unknown, we currently keep the original name of Mey (1967) for these strata in order to keep the nomenclatorial burden as low as possible. This has also been briefly explained by Valenzuela-Ríos \& Liao (2006) who maintained the initial meaning of the Renanué sub-facies area, but with an up-date of the age of this unit.

The facts briefly presented above show the complexity of the Devonian stratigraphy in the Pyrenees; besides the problem of lithological assignment, the age of many rock-units is not known in detail. A general preliminary summary was presented in Valenzuela-Ríos \& Sanz-López

Figure 2. Lithostratigraphic column of Renanué section with ranges of selected conodont taxa, levels with microfacies studies, sea-level curve and indication of other fossils. Legend of lithologic and paleontologic data. Abbreviations: CSZ - Conodont Standard Zonation, EIF. - Eifelian, Lw. - Lower, $\mathrm{R}$ - regression, $\mathrm{T}$ - transgression, Up. v. - Upper varcus.

\begin{tabular}{|c|c|c|c|}
\hline & Limestones & & Colonial corals \\
\hline- & \multirow{3}{*}{ Marly limestones } & & Solitary corals \\
\hline & & & \\
\hline - & & & Fish scales \\
\hline & \multirow{2}{*}{$\begin{array}{l}\text { Calcareous marls } \\
\text { Nodular marly limestones }\end{array}$} & & Fish teeth \\
\hline 운 & & \# & Bryozoa \\
\hline$\vdots$ & \multirow{3}{*}{$\begin{array}{l}\text { Massive limestones } \\
\text { Nodular marls with } \\
\text { muddy-limestone } \\
\text { lenses }\end{array}$} & & Trilobites \\
\hline $\bar{z}=$ & & & Foraminifers \\
\hline & & & Channel \\
\hline & Black shales & & Lamination \\
\hline
\end{tabular}

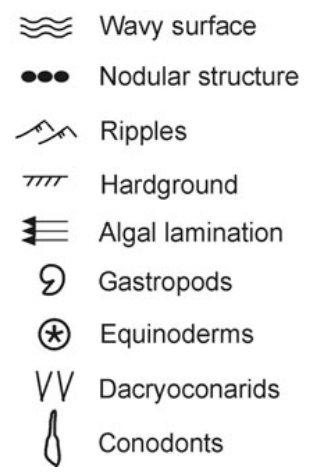


Jau-Chyn Liao et al. • Depositional environment interpretation and development of the Renanué section

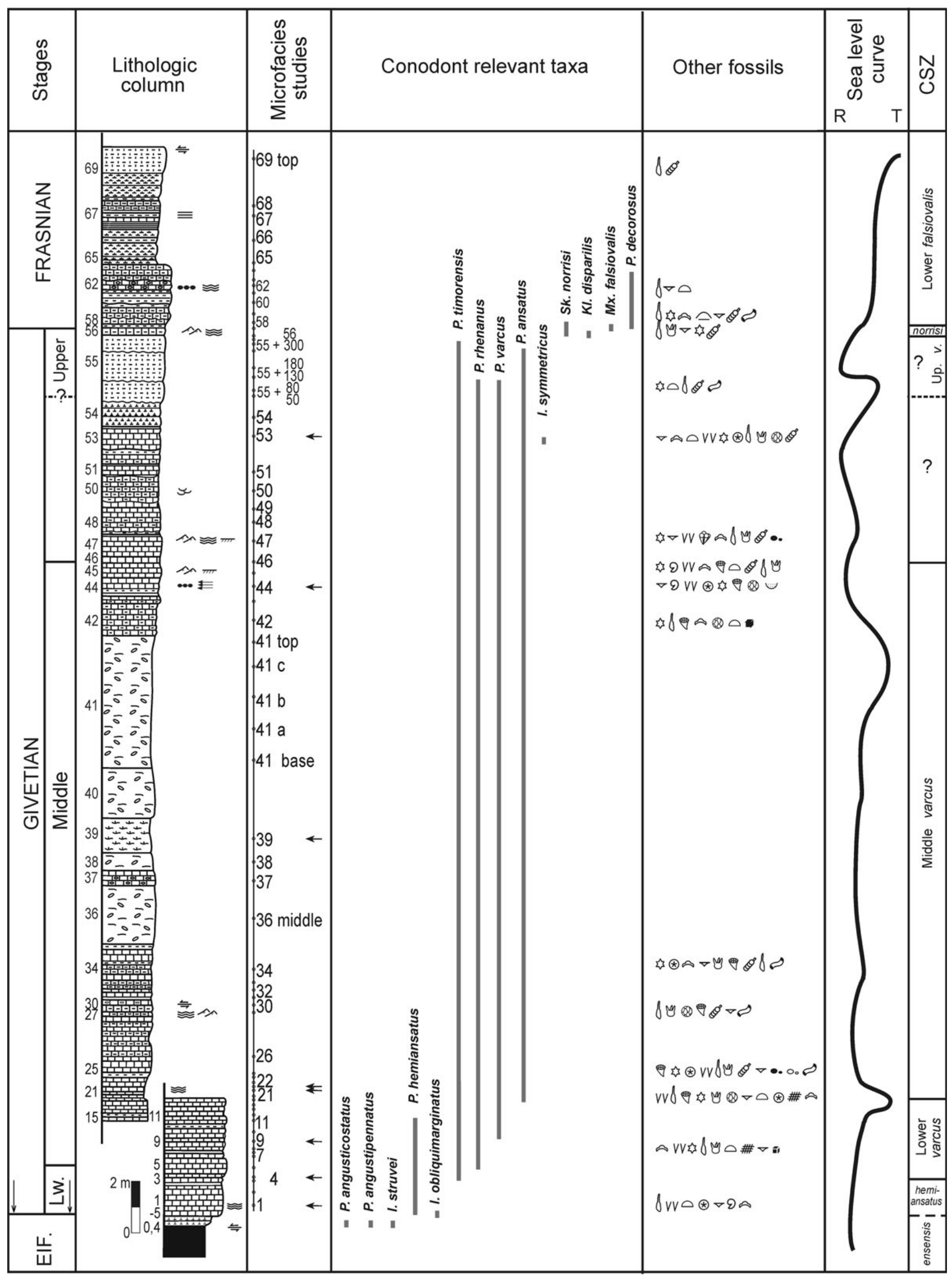


(2002) and Sanz-López (2002) and up-dated for the "Southern facies area" by Valenzuela-Ríos \& Liao (2006). These data provide important general information, but the needed details for attempting multidisciplinary studies aiming at the reconstruction and evolution of the different Devonian Pyrenean basins are still lacking. In undertaking such studies, we need to combine litho- and biofacies information, with chronostratigraphic control as detailed as possible and with the analysis of microfacies. We have just started such combined studies (Liao et al. 2005) and applied them to the Renanué section and here we present the results. The aim of this report is, therefore, to analyse the evolution of litho- and biofacies from the section Renanué and their comparison with sea-level changes.

\section{Geographical setting}

The section Renanué is located in a former limestone quarry on the national road N-260, approximately $1 \mathrm{~km} \mathrm{~N}$ of the village of Renanué (Fig. 1). The section consists of a basal shaly interval ( $4 \mathrm{~m}$ of dark shales with a few thin sandy lenses) that is followed by about $50 \mathrm{~m}$ of limestones with some intercalated marls (Fig. 2, 3); the contact between both lithologies is tectonised. Therefore, it is not easy to determine whether the dark shales represent the Kačák-otomari Event (Walliser 1984, 1985; House 1985). The age of the section spans from the upper Eifelian to the Lower Frasnian, and contains a sequence very rich in conodonts for some parts of the Givetian and Lower Frasnian, which has been preliminary reported by Liao et al. (2001).

\section{Biostratigraphical outline}

The basal limestone (sample Re'04, Fig. 2, 3) yielded Polygnathus angusticostatus, $P$. angustipennatus and Icriodus struvei (abundant). They indicate the uppermost Eifelian, ensensis conodont Zone. Besides, P. pseudofoliatus and P. eiflius, which span the Eifelian/Givetian boundary, have also been recorded in this sample.

The lowest occurrence of $P$. hemiansatus in bed $\operatorname{Re}(-5) 2$ $\mathrm{m}$ above Re'04 indicates the base of the hemiansatus Zone, which coincides with the base of the Givetian. This taxon is accompanied in bed $\operatorname{Re}(-5)$ by $I$. obliquimarginatus, P. pseudofoliatus, P. eiflius, P. xylus, P. ovatinodosus, P. linguiformis, $P$. l. weddigei and P. l. klapperi.

The entry of $P$. timorensis in bed 3 marks the beginning of the timorensis Subzone of the Lower varcus Zone. The entry of $P$. rhenanus in bed 5 marks the beginning of the rhenanus/varcus Subzone. It is worth noting that the other index taxon ( $P$. varcus) does not appear before bed 10. Further taxa that occur in the Lower varcus Zone in the
Renanué section are numerous specimens of I. difficilis, I. regularicrescens, I. expansus and a few specimens of I. lindensis and I. brevis.

The lowest entry of $P$. ansatus in bed 19 indicates the beginning of the Middle varcus Zone and, therefore, the beginning of the Middle Givetian. In this bed I. eslaensis is also recorded. I. latericrescens latericrescens is first recorded from bed 21.

Absence of $P$. latifossatus precludes recognition of the Middle/Upper varcus boundary; however, the highest record of $P$. xylus ensensis in bed 45 indicates that this bed still belongs to the Middle varcus Zone. Worldwide, most records of $P$. rhenanus do not reach the Upper varcus Zone; however, Aboussalam (2003) has reported from the Burgberg section (Rheinisches Schiefergebirge, Germany) one specimen from bed 41 that, without proper data, she assigned to the "semialternans-Zone?" Our last record of $P$. rhenanus comes from bed 55, suggesting that the Upper varcus Zone is close to this bed, probably above it, but lack of informative taxa precludes better precision between beds 46 and 55.

The lowest record of Skeletognathus norrisi in bed 56 together with Klapperina disparilis enables recognition of the uppermost Givetian norrisi Zone. Between these two records (beds 55 and 56), which are separated by $330 \mathrm{~cm}$, eight samples were taken, but detailed zonation cannot be achieved; the only indirect valuable data is the highest record of $P$. ansatus in bed 55+336 suggesting that the uppermost part of 55 could belong to the upper disparilis Zone. The Givetian/Frasnian boundary is traced at the base of bed 57 with the occurrence of Mesotaxis falsiovalis and P. decorosus.

\section{Microfacies analysis}

The main parts of the Renanué section are composed of open-marine carbonates with subordinate marls. Common microfacies types are dark grey to light grey and even reddish mudstones and wackestones as well as some packstones, rudstones, calcarenites and grainstones. The limestones are generally thin to medium bedded and sometimes strongly bioturbated.

Because of the faulted contact at the top of the Eifelian black shale (ensensis Zone), description of microfacies samples starts slightly above this level (Fig. 2). Beds 1-12 are mainly composed of bioclastic wackestones (Fig. 4A, sample Re1) and rare packstones. The matrix commonly consists of micrite or pelmicrite and contains very small skeletal debris. Remains of brachiopods, ostracods, gastropods, conodonts, bryozoans and echinoderms are present in the wackestones. A packstone rich in styliolinid dacryoconarids occurs in the lower part of the section 


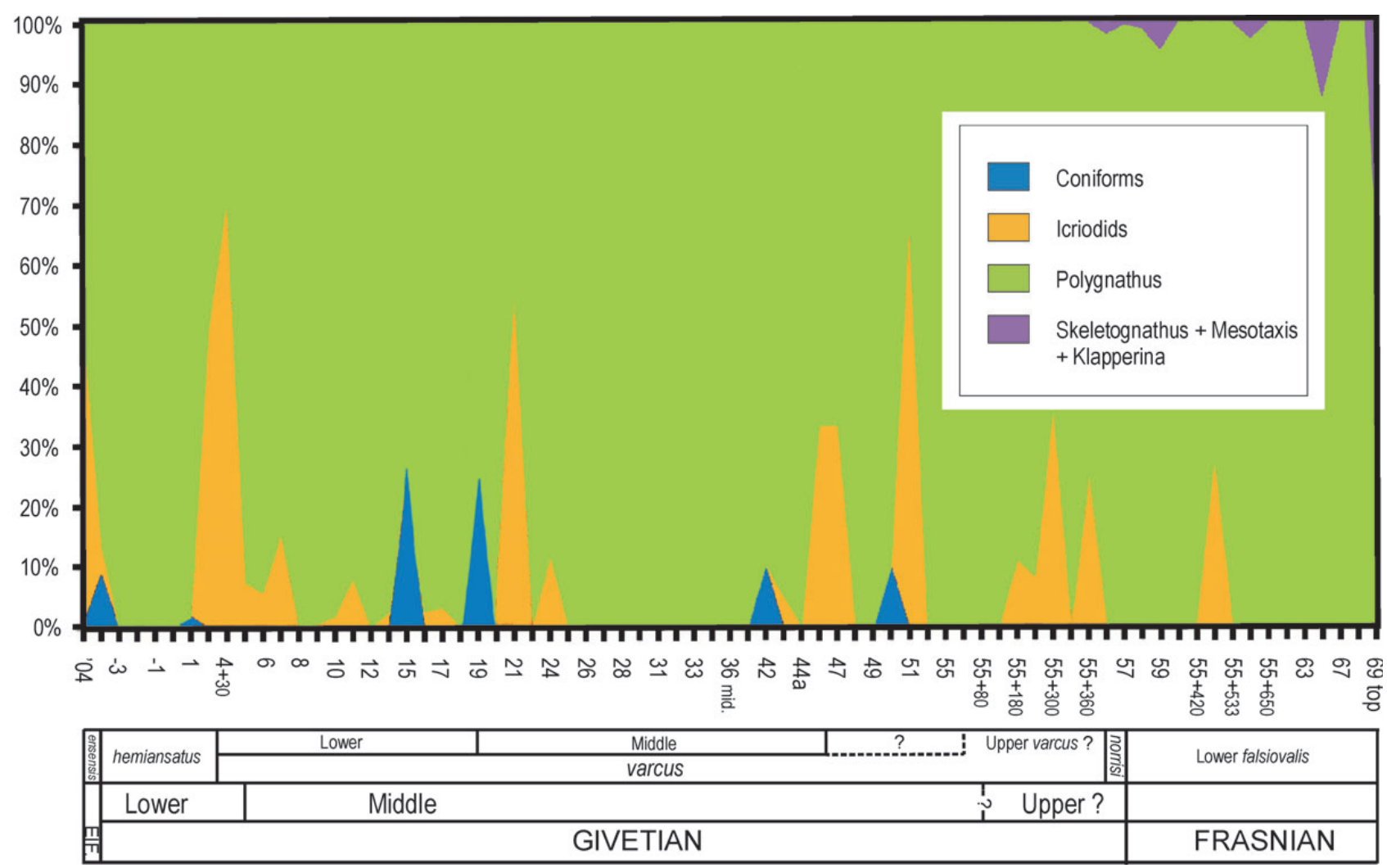

Figure 3. Conodont richness distribution (biofacies).

(Fig. 4B, sample Re4). The bioclastic mudstones and wackestones with variable fossil content - in some mudstones trilobites preferably occur (e.g., Fig. 4C, sample $\operatorname{Re} 9)$ - continue up to bed 16.

The fauna above bed 16 is more diverse, especially around the boundary of the Lower to Middle varcus Zone (Fig. 2). The overlying limestones are characterized mainly by wackestones similar to those described above. The microfauna is well preserved and dominated by trilobites, ostracodes, dacryoconarids and crinoids (Fig. 4D, sample Re21). The micritic matrix contains small skeletal debris and the sediment is poorly sorted. The overlying limestone (bed Re22) is also poorly sorted, but yields a more diverse fauna including reworked shallow water fauna, such as crinoid (Fig. 4E, sample 22). The overlying sequence (up to bed 41) is composed of calcisiltites (Fig. 4F, sample Re39), mudstones, and wackestones containing rare fauna which is also smaller-sized. The siliciclastic input in this part of the sequence increases, especially in beds 36 and 37 up to bed 41. From bed 42 onwards, well-bedded carbonates occur. The sample Re43 is dominated by poorly-sorted and fragmented bioclasts. In comparison to the underlying sequence the faunal diversity increases.

Within the upper half of the Middle varcus Zone bed 44 comprises an oncoid rudstone (Fig. 4G, sample Re44). The oncoids are produced by cyanobacteria and are millimeter- to centimeter-sized, forming a grain-supported fabric. The shape of the oncoids (mainly ellipsoidal) is mainly controlled by the shape of the brachiopds (complete shells or shell fragments) and some gastropods. The irregular nobbly surface of the oncoids indicates no abrasion and/or long transport from their shallow-water origin (SMF 13, FZ 6). The next interval (beds 45-48) is characterized by pure limestones. In this part mainly grainstones occur, wackestones are subordinate. The intergranular pores of the grain-supported fabric is composed of micrit and calcite cement. The limestones are characterized by sharp erosional surfaces (e.g., sample Re46). The interval from bed 49 to 52 contains mainly bioclastic wackestones and mudstones (SMF 3), partly bioturbated. The fauna is characterized by trilobites, ostracods, crinoids, gastropods and conodonts. The next limestone (bed 53) is an allochthonous bioclastic grainstone (SMF 5). The bioclasts are mainly formed by fragments of echinoderms and brachiopods (Fig. 4H, sample Re53). The following sequence is characterized by wackestones and calcarenites. The fossil content is low, only some trilobite fragments occur. After a gap spanning the hermanni to disparilis conodont zones in the uppermost part of the Givetian, the section continues with wackestones in the norrisi to falsiovalis conodont zones. At the base of the Early falsiovalis Zone wackestones with mainly pelagic fauna occur. In comparison to the faunal diversity in the 
Middle Devonian, the fauna of the lowermost Upper Devonian is less diverse. In the Early falsiovalis Zone mainly wackestones with more pelagic fauna occur.

\section{Conodont biofacies}

In the Renanué section, the polygnathid conodont biofacies prevails throughout the Givetian and Lower Frasnian with values higher than $90 \%$ polygnathid conodonts in many samples; however, a few peaks of icriodont biofacies are present. In the uppermost Eifelian (sample Re'04) a mixed icriodontid-polygnathid (exactly $49.6 \%$ of both genera $\mathrm{Po}$ lygnathus and Icriodus) biofacies occur. The conodont biofacies changes in the lowermost Givetian hemiansatus Zone which is characterized by a polygnathid biofacies (from $86.3 \%$ to $100 \%$ of the genera Polygnathus). The basal beds of the timorensis Zone are characterized by icriodontid biofacies. The conodont biofacies changes again in beds 15 and 16, where the number of Polygnathus is increasing, and in these beds the number of coniform elements (belodellids) is higher than $20 \%$ whereas that of icriodids drops to less than $3 \%$.

Beds $17-20$ are characterized by the polygnathid biofacies, but rates and composition are variable; in beds 17 and 19 (bed 18 contains 100\% Polygnathus) the dominant non-polygnathid elements are the coniform elements (9.7\% and $24.6 \%$, respectively). In bed 20 icriodids (6.3\%) are the only non-polygnathid elements. Bed 21, slightly above the Lower-Middle varcus Zone, shows a strong peak of icriodids (56\%). Above, the polygnathid biofacies is dominant with always more than $88 \%$ Polygnathus and many beds yield nothing else but this genus. Also the accompanying genera change a little; in bed 24 , Icriodus
(11.8\%) is the supplementary taxon, whilst in bed 42 Belodella is the concurrent taxon (up to 10.3\%). Finally, in bed 43, Icriodus comes back, as accessory taxon (up to $5 \%)$. It is important to note than many beds of this interval (17-43) are very poor in conodonts: e.g., bed $31(9.9 \mathrm{~kg})$ yielded 11 specimens; bed $32(5.3 \mathrm{~kg})$ three specimens; 36 middle $(7.4 \mathrm{~kg})$ four specimens, which contrast highly with the richness of, for instance, bed $42(5.5 \mathrm{~kg})$ that yielded 300 specimens.

Bed 44 is also very poor in conodonts, and three consecutive samples totalizing $7.8 \mathrm{~kg}$ have only yielded one single specimen of Polygnathus. The polygnathid biofacies is dominant in beds $45-48$, but records are too poor. Additional samples could easily change the picture; for instance, sample Re47 (7.3 kg) yielded two Polygnathus and one Icriodus. Insufficient conodont record continues, but there is an apparent shift in biofacies from bed $49(100 \%$ polygnathids) to bed 51 that represents the icriodid biofacies. But, as pointed out above, conodont numbers are still poor so the conodont biofacies intepretation is very limited in that part of the section.

From bed 56 onwards, the sequence is characterized by the polygnathid biofacies (many samples 100\% Polygnathus), but there is a change in composition from the Givetian to Frasnian. Upper Givetian samples have Icriodus rates from $7.7-28.6 \%$ (beds $55+180-55+360$ ); in the norrisi Zone Icriodus counts only for $0.2 \%$ and in the lower Frasnian the genus has completely disappeared. The main accompanying genus in some beds of the lowermost Frasnian of Renanué is Klapperina (2.8-12.5\%). The last bed (69) represents also a slight shift in composition and ratio; the biofacies is made up by two genera Polygnathus and Mesotaxis, which have accounted $61.5 \%$ and $38.5 \%$, respectively.

Figure 4. Microphotographs of selected thin sections (for location in the section see Fig. 2). $•$ A - wackestone to packstone with abundant bioclasts from the lowermost part of the limestone succession of the Renanué section. The components consist mainly of micro-peloids and fragmented shells (brachiopods, gastropods) and to a lesser degree, crinoid remains. As no sedimentary structures indicating shallow-water conditions are present, the bed reflects quiet-water conditions (i.e., below storm wave base, SWB - outer shelf/ramp or upper slope, respectively). Sample Re1, width of field of view $(\mathrm{FV})=5 \mathrm{~mm}$. $\bullet \mathrm{B}$ - packstone with numerous dacryoconarids (longitudinal and cross sections). Ostracods and echinoderm fragments are also present. Some of the reworked dacryoconarid and crinoid bioclasts are filled with micrite - some contain very fine aggregates of iron oxide. Sample Re4; width of $\mathrm{FV}=4 \mathrm{~mm}$. $\cdot \mathrm{C}-$ strongly recrystallized micritic mudstone/wackestone with rare bioclasts. Besides few crinoid fragments, cross sections of dacryoconarids of small spines of uncertain origin (?spiculae) and an isolated trilobite fragment are visible. As in Fig. 4B, some aggregates of iron oxide are present. Sample Re9; width of FV $=3 \mathrm{~mm}$. $\bullet$ D - poorly sorted wackestone (slightly recrystallized) with well preserved trilobite (cross-section of a thorax segment [T]) and ostracods (geopetal visible in an ideal cross section). Sample Re21; width FV $=3$ mm. $\bullet$ E - bioclastic wackestone/packstone with a diverse skeletal fragments of many different organisms, e.g., ostracods, brachiopods, crinoids (including a probable echinid spine - upper right of the center, bryozoans, trilobites). Sample Re22, width of FV $=4 \mathrm{~mm} . \cdot \mathrm{F}$ - well-sorted biolithoclastic calcisiltite rather distally deposited in an outer shelf environment. Little variation in accessory micrite is indicated by pressure solution sutures. Sample Re39; width of FV = 5 mm. $\bullet \mathrm{G}-$ oncoid rudstone (SMF 13 after Flügel 2004). The cores of the oncoids are mainly consisting of brachiopods and rare gastropods. Some oncoids are compacted and dissolved (arrow lower left). Dark clay seems to have resulted from incipient pressure solution. Long-distance transport of the oncoids generated under shallow-water conditions can be excluded because of the preserved nobbly surface of the specimens. Deposition may have taken place close to the fair-weather wave base. Sample Re44; width of FV $=2.5 \mathrm{~cm}$. $\bullet \mathrm{H}$ - poorly sorted crinoidal grainstone, densely packed. Fragments often show pressure solution contacts between grains. Porosity was considerably reduced, and the remaining inter-particle space was filled by blocky marine calcite cement. Some of the crinoid ossicles were altered by microborings and micritized on the surface. Depositional environment can be assigned to SMF 5 (after Flügel 2004 ) on an upper slope near or above the fair-weather wave base. Sample Re53; width of FV $=7 \mathrm{~mm}$. 

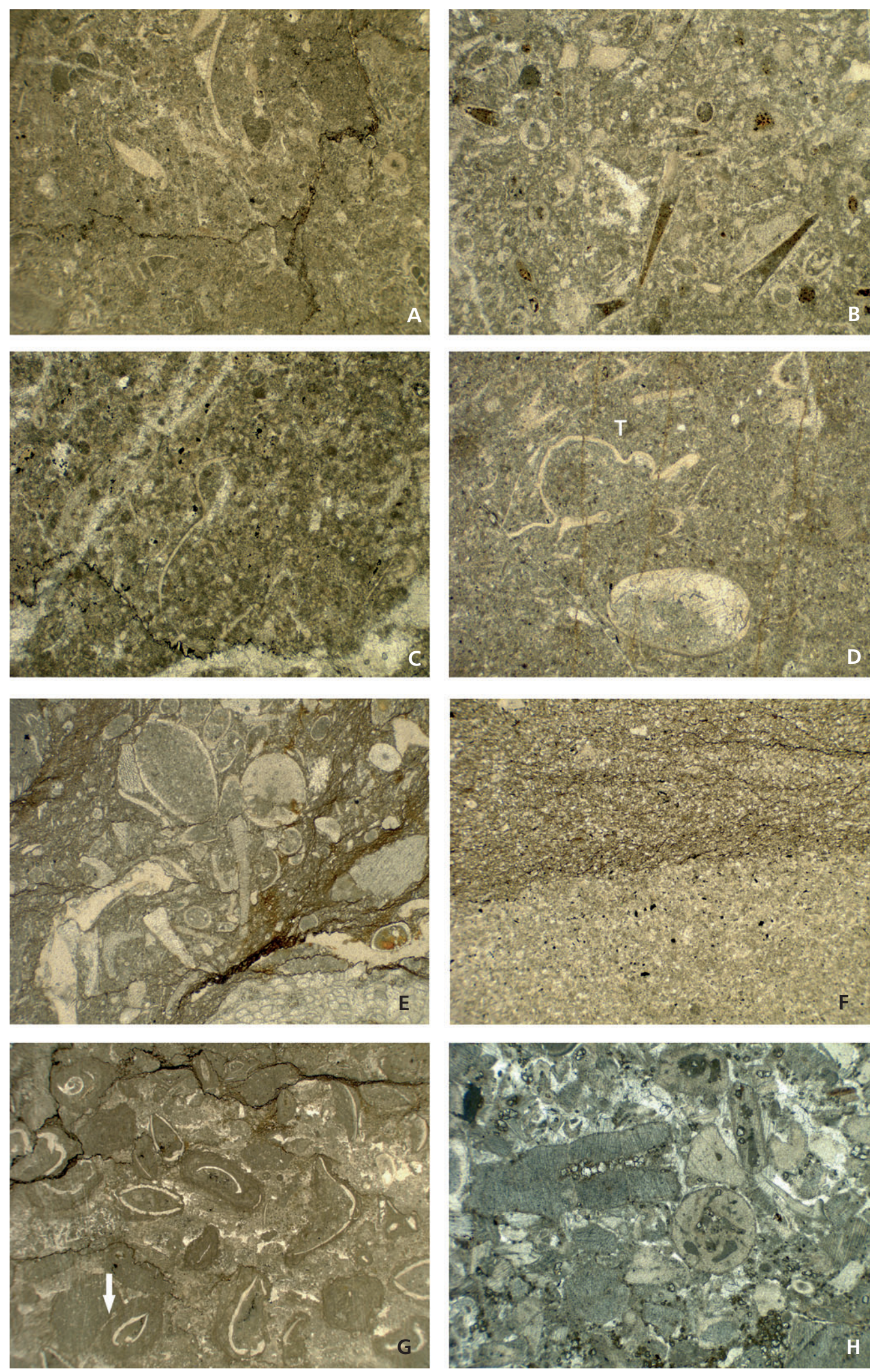


\section{Discussion}

Open-marine carbonates were deposited over a wide range of settings from continental margins on drowned carbonate platforms to slopes and basins (e.g., Tucker 1974, Wendt \& Aigner 1985). The general depositional environment of the Renanué section based on sedimentary structures and microfacies predominantly belonging to an outer shelf setting (according to Wilson's modified Standard Facies Zones in Flügel 2004) with remarkable effects of changing biodiversity and microfacies, which might be the result of sea-level fluctuations.

Limestones of the uppermost Eifelian ensensis Zone are characterized by the icriodid-polygnathid biofacies. In contrast, the Givetian and Lower Frasnian conodont faunas represent the polygnathid biofacies with three main icriodid peaks, one at the base of the Lower varcus Zone (beds 3 and 4); a second one in the lower part of the Middle varcus Zone (Bed 21) and the third one in the upper half of the Middle Givetian (beds 51, 53); however, and due to inadequate conodont record in many beds, these data (especially the third main peak) have to be taken with caution. In the lowermost Frasnian there is a shift in the biofacies composition, the genus Icriodus is substituted by the genera Klapperina and Mesotaxis.

The Renanué section displays lithological and facial characters that allow sequence stratigraphic interpretations even though we have not analysed thin sections from each layer of the section (microfacies data are based on more than 90 thin sections). Abrupt facies changes occur always with the income of limestone beds, which can be interpreted as the beginning of single transgressive phases. Transgressive pulses from the Givetian have been also reported from more shallow-water environments in many other areas (e.g., Bultynck 1982, Brett 1995, Brett et al. 1997). Remarkable changes within the Renanué section are documented by increasing faunal diversity. Some of these limestones consist of bioclast-rich grainstones which might indicate transgressive pulses, such as layer Re22 (Fig. 4E) that is placed around the Lower-Middle varcus zonal boundary. Whether this level represents a more lo$\mathrm{cal} /$ regional or even an eustatic sea-level fluctuation is uncertain. The overlying units contain mainly wackestones and mudstones with an increase in siliciclastic material. The prominent sharply defined limestone interval (beds 42-47) shows an abrupt lithologic break reflecting a sudden episode in the upper half of the Middle varcus Zone. It starts with bed 42 probably echoing the beginning of a transgressional phase. The occurrence of reworked oncoid rudstones (Re44, Fig. 4G) can be correlated with a highstand deposit. T-R cycles have been identified in the varcus Zone up to the falsiovalis Zone (Johnson et al. 1985, Johnson \& Sandberg 1988). It seems possible that bed 44 (upper part of the Middle varcus Zone) represents the main transgressive level which might be correlated with the Taghanic Event (Johnson 1970, House 1985, Aboussalam 2003). A transgression at the base of the regional Taghanic Stage or at the base of the Tully Limestone (Middle varcus Zone) of New York was assumed to represent the main event level and a second transgression was placed at the top of the Tully Limestone (base of the Lower hermanni Zone). Bultynck (1982) also showed that significant transgressive pulses occurred in Belgium in the Middle varcus Zone at the base of the Fromelennes Formation. Another transgressive pulse could may be present close to the uppermost(?) part of the Middle varcus Zone or lower part of the Upper varcus Zone (bed 53; see above) where allochtoneous bioclastic grainstones occur (similar to bed 22).

The uppermost part of the section includes a gap spanning significant parts of the Givetian (hermanni to disparilis zones, at least). Sedimentary rocks below can be characterized as calcarenites. Contourites is the generally accepted term for those sediments that have been deposited by and/or significantly affected by the activity of bottom currents (Stow et al. 2002). Such current-influenced pelagic lithofacies occur also in Devonian rocks and have been studied by Franke \& Walliser (1983), Wendt et al. (1984), and Wendt (1991). The gap above those sediments in the Renanué section is constrained solely by conodont biostratigraphy. No sedimentological indications in the field or in thin sections such as hardgrounds and/or erosion surfaces have been found so far. The question arises: what might be the reason for that gap? Recently, Hüneke (2006) reported hiatuses in bottom-current deposits in pelagic and hemipelagic Devonian sequences in Morocco and Europe. It is interesting to note that Upper Givetian sections in the Harz Mountains have shown the same stratigraphic range of the gap (hermanni to disparilis zones) indicating a regional disconformity (Hüneke 1995, 1997). Hiatuses of the same stratigraphical level have been reported also from other regions, e.g., in the Carnic Alps and the Rheinisches Schiefergebirge (Schönlaub 1985, House \& Ziegler 1977, Aboussalam 2003). In comparison to their investigations it is possible that the paraconformity in the Renanué section might also be explained by considerable bottom-current influence on sedimentation. It remains questionable whether this pattern is connected with the second transgression of the Taghanic Event (Johnson 1970, House 1985, Aboussalam 2003), which was placed at the top of the Tully Limestone in the United States (base of the Lower hermanni Zone).

\section{Conclusions}

The general depositional environment of the Renanué section belongs to an open shelf with varying water depth. This interpretation is supported by the occurrence of mainly pelagic fauna, conodont biofacies and the dominant occur- 
rence of wackestones, mudstones, calcisiltites and subordinate grainstones and rudstones (Fig. 2).

Most of the wackestones have been deposited in a deeper open shelf environment and/or on an intrabasinal swell, showing fine-grained matrix and strong bioturbation, which occurs in many of these limestones. The origin of the fine-grained matrix of the limestones can be explained as resulting from a breakup of macroskeletons. Although calcisiltites are common in shallow marine lime mud environments (Folk \& Robles 1964), they also occur in deeper-water ramp, slope and basinal settings (Flügel 2004).

The Givetian biofacies (polygnathid dominant with three main icriodid peaks) contrast with those of the upper Eifelian (polygnathid-icriodid) and Lower Frasnian at Renanué. However, the third icriodid peak is based on very few specimens and impedes sound comparison with other data. The combination of micro- and biofacies data does not show a clear direct correlation between icriodid peaks and shallower water depth; this fact suggests that there is a need, at least, for a revision of such engraved concepts and for combined studies to test such inferences.

Progress on deciphering local T-P pulses are presented; their relation to global events and regional patterns needs further work and cannot be satisfactorily achieved yet. We have identified the following major transgressive pulses in the Renanué section (from oldest to youngest): 1) around the Lower/Middle varcus Zones; 2) within the Middle varcus Zone; 3) in Upper varcus Zone, but data here do not allow precise stratigraphic alignment and 4) in the Lower Frasnian.

The transgressive pulse in the Middle varcus approximately coincides in time with the beginning of the Taghanic event, but a direct correlation of both facts is still tentative.

The Upper Givetian paraconformity in the Renanué section and its global (or at least, supraregional) relations are still not well understood, and the possible explanations discussed above are still speculative.

\section{Acknowledgements}

This work has been partially founded by the DAAD and UNESCO/IUGS IGCP 499 (J.-C. L.), by the Alexander von Humboldt-Stiftung (J.I. V.-R.), and by the Spanish Research Project DGICT-BTE 2003-02065. We thank Mrs. Carmen Pueyo Castán and her family the hospitality during field-work. This is a contribution to IGCP 499, "Devonian land-sea interaction: evolution of ecosystems and climate" (DEVEC).

\section{References}

ABoussalaM, Z.S. 2003. Das "Thaganic-Event” im höheren Mittel-Devon von West-Europa und Marokko. Münstersche Forschungen zur Geologie und Paläontologie 97, 1-332.
Boersma, K.T. 1973. Devonian and Lower Carboniferous conodont biostratigraphy, Central Spanish Pyrenees. Leidse Geologische Mededelingen 49, 303-377.

BRETT, C.E. 1995. Sequence stratigraphy, biostratigraphy, and taphonomy in shallow marine environments. Palaios 13, 241-262. DOI $10.2307 / 3515448$

Brett, C.E., BAIRD, G.C. \& Ver Straeten, C.A. 1997. Middle Devonian (latest Eifelian-Givetian) cycles, sequences, and bio-events in the north-central appalachian basin. International meeting on Cyclicity and Bioevents in the Devonian System. Program and Abstracts, Subcommission on Devonian Stratigraphy, 21.

BULTYNCK, P. 1982. Conodont succession and general faunal distribution across the Givetian-Frasnian boundary beds in the type area with contributions by Luc Jacobs. Papers on FrasnianGivetian boundary: Ministry of Economic Affairs, Administration of Mines, Geolological Survey of Belgium, 34-59.

DALloni, M.M. 1910. Etude géologique des Pyrénées de l'Aragon. Annales Facultaire de Sciences de Marseille 19, $1-144$.

FLÜGEL, E. 2004. Microfacies of carbonate rocks. 976 pp. Springer, Berlin \& Heidelberg.

FOLK, R.L. \& Robles, R. 1964. Carbonate sands of Isla Perez, Alcaran Reef Complex, Yucatan. Journal of Geology 72(3), 255-292.

FRANKE, W. \& WALliSER, O.H. 1983. Pelagic carbonates in the Variscan belt - their sedimentary and tectonic environments, 77-92. In MARTIN, H. \& EDER, F.W. (eds) Intracontinental fold belts. Springer, Berlin \& Heidelberg.

HARTEVELT, J.J.A. 1970. Geology of the Upper Segre and Valira valleys, Central Pyrenees, Andorra/Spain. Leidse Geologische Mededelingen 45, 167-236.

House, M. 1985. Correlation of mid-Palaeozoic ammonoid evolutionary events with global sedimentary perturbations. $\mathrm{Na}$ ture 313, 17-22. DOI 10.1038/313017a0

House, M. \& ZIEGLER, W. 1977. The goniatite and conodont sequences in the early Upper Devonian at Adorf, Germany. Geologica et Palaeontologica 23, 99-123.

HÜNEKE, H. 1995. Early Devonian (Emsian) to Late Devonian (Famennian) stratigraphy and conodonts of the Antoinettenweg section in the Lower Harz Mountains (Germany). Courier Forschungsinstitut Senckenberg 188, 99-131.

HÜNEKE, H. 1997. Die Hercynkalke am Rande der Selke-Einheit (Harz) - Schrittweiser Übergang von neritischer Akkumulation zur pelagischen Kondensation während des Devons. Neues Jahrbuch für Geologie und Paläontologie Abhandlungen 205, 209-264.

HÜNEKE, H. 2006. Erosion and deposition from bottom currents during the Givetian and Frasnian: Response to intensified oceanic circulation between Gondwana and Laurussia. Palaeogeography, Palaeoclimatology Palaeoecology 234, 146-167. DOI 10.1016/j.palaeo.2005.09.033

JOHNSON, J.G. 1970. Taghanic onlap and the end of North American provinciality. Bulletin of the Geological Society of America 81, 2077-2106.

DOI 10.1130/0016-7606(1970)81[2077:TOATEO]2.0.CO;2 
Johnson, J.C., Klapper, G. \& SAndBerg, C.A. 1985. Devonian eustatic fluctuations in Euramerica. Bulletin of the Geological Society of America 96, 367-387. DOI 10.1130/0016-7606(1985)96<567:DEFIE >2.0.CO;2

Johnson, J.C. \& SANDBERG, C.A. 1988. Devonian eustatic events in the western United States and their biostratigraphic responses. In MCMILlan, N.J., EMBRY, A.F. \& GlaSS, D.J. (eds) Devonian of the World, III. Canadian Society of Petroleum Geology Memoire 14, 171-178.

LiaO, J.-C., VAlENZUEla-Ríos, J.I. \& RODRÍGUEZ, S. 2005. Givetian and Lower Frasnian conodonts from Renanué (Aragón, Spanish Central Pyrenees). $15^{\text {th }}$ International Senckenberg Conference, IGCP 421/SDS Meeting, 65.

LiAO, J.-C., KÖNIGSHOF, P., VALENZUEla-RIOS, J.I. \& SCHINDLER, E. 2005. Palaeoenvironmental and development of a Givetian section from the Aragonian Pyrenees (N. Spain). International Conference "Devonian terrestrial and marine environments: from continent to shelf, Novosibirsk, July 25-August 09, 2005, 96-97.

MEY, P.H.W. 1967. Evolution of the Pyrenean Basins during the Late Palaeozoic. International Symposium on the Devonian System 2, 1157-1166.

SANZ-LÓPEZ, J. 2002. Devonian and Carboniferous preStephanian rocks from the Pyrenees, 367-389. In GARCÍALÓPEZ, S. \& BASTIDA, F. (eds) Palaeozoic conodonts from Northern Spain. Instituto Geológico y Minero de Espańa, serie Cuadernos del Museo Geominero 1.

SCHÖNLAUB, H.-P. 1985. Das Paläozoikum der Karnischen Alpen, 34-52. In SCHÖNLAUB, H.-P. (ed.) Arbeitstagung der Geologischen Bundesanstalt. Geologische Bundesanstalt Österreich, Vienna.

Stow, D.A.V., Faugeres, J.C., Howe, J.A., Pudsey, C.J. \& Viana, A.R. 2002. Bottom currents, contourites and deep-sea sediment drifts: current state-of-the-art, 7-20. In STOW, D.A.V., Pudsey, C.J., Howe, J.A., FAugeres, J.C. \& VIANA, A.R. (eds) Deep-water Contourite Systems: Modern
Drifts and Ancient Series, Seismic and Sedimentary Characteristics, Geological Society of London Memoir 22.

TUCKER, E. 1974. Sedimentology of Palaeozoic pelagic limestones: the Devonian Griotte (southern France) and Cephalopodenkalk (Germany), 71-92. In HSÜ, K.J. \& JENKINS, H.C. (eds) Pelagic sediments: On Land and Under the Sea. International Association of Sedimentologists Special Publication 1.

VALENZUELA-RíOS, J.I. \& LIAO, J.-C. 2006. Annotations to Devonian Correlation Table, R 357-360 di-ds 06: Spanish Central Pyrenees, southern part. Senckenbergiana lethaea 86(1), 105-107.

VAlEnZuela-Ríos, J.I. \& SANZ-LÓPEZ, J. 2002. Pyrenees, 86-89. In GiBBONS, W. \& MORENO, T. (eds) The geology of Spain. 649 pp. Geological Society of London, London.

WALLISER, O.H. 1984. Geologic processes and global events. Terra Cognita 4, 17-20.

WALLISER, O.H. 1985. Natural boundaries and Commission boundaries in the Devonian. Courier Forschungsinstitut Senckenberg 75, 401-408.

WENDT, J. 1991. Depositional and structural evolution of the Middle and Late Devonian on the northeastern margin of the Sahara Craton (Morocco, Algeria, Lybia), 2195-2210. In SALEM, M.J., SBETA, A.M. \& BAKBAK, M.R. (eds) The geology of Libya 6. Elsevier, Amsterdam.

WENDT, J. \& AIGNER, T. 1985. Facies patterns and depositional environments of Palaeozoic cephalopod limestones. Sedimentary Geology 44, 263-300. DOI 10.1016/0037-0738(85)90016-8

WendT, J., Aigner, T. \& Neugebauer, J. 1984. Cephalopod limestone deposition on a shallow pelagic ridge: the Tafilalt Platform (Upper Devonian, eastern Anti-Atlas, Morocco). Sedimentology 31, 601-625. DOI 10.1111/j.1365-3091.1984.tb01226.x

ZWART, H.J. 1979. The geology of the Central Pyrenees. Leidse Geologische Mededelingen 50, 1-74. 